\title{
GENETIC ASPECTS OF INFLAMMATION IN CHILDREN WITH BRONCHIAL ASTHMA IN ASTRAKHAN REGION
}

\section{Tatiana Stroykova ${ }^{\bowtie}(\mathbb{D}$, Ekaterina Seliverstova, Diana Sergienko (1D}

Astrakhan State Medical University, Astrakhan, Russia

mega.astor@mail.ru

\begin{abstract}
The search for genetic markers that control the key links in the pathogenesis of bronchial asthma is relevant. Identification of the association of polymorphic loci of candidate genes with a risk of developing severe forms of bronchial asthma in children is regarded as most promising. A frequent change in the structure of genes is associated with the single nucleotide polymorphisms, which affect the phenotype of the disease and determine differences in the clinical manifestations of the same nosological entity.
\end{abstract}

KEYWORDS - asthma, children, gene polymorphism, genotypes, alleles, cytokines, inflammation.

\section{B A C K GROUND}

Bronchial asthma (BA) is a phenotypically heterogeneous disease that is difficult in the timely diagnosis of this disease especially in children. A number of authors note a significant increase in the prevalence of asthma in children over the past 25 years $[1,4,5]$. A study of the genetic aspects of asthma in Russia was focused on studying the polymorphism of interleukin ligand and receptor genes, assessment of their expression. The results confirmed the important role of the genetic component in controlling inflammation in bronchial asthma. Currently, great successes have been achieved in the study of the pathogenesis of bronchial asthma, however, many stages of the formation and modification of the course of this disease are controversial and not entirely clear. Perhaps the lack of adequate control over the course of the disease is due to the peculiarities of the endogenous regulation of cell-cell interactions carried out by cytokines - regulators of both non-specific inflammatory processes and the allergen-specific immune response of the cellular and humoral types $[7,10]$.

Among a large number of candidate genes for BA and atopy, the attention of researchers is largely attracted to the IL- 4 gene. It is often called the critical cytokine of inflammation $[3,6,8,9]$. Studies of its already known polymorphisms related to BA and atopy as well as the search for new mutations of this gene are of great interest $[5,7,8,11]$.

$$
\text { Objective }
$$

is to analyze the IL- 4 gene polymorphisms at C-590T gene in children with bronchial asthma of Astrakhan population, to study the associations of this gene polymorphism with some clinical and anamnestic indicators.

\section{MATERIALS AND METHODS}

Study was prospective full-design. The population of children living in the territory of the Astrakhan region was examined. The control group was represented by conditionally healthy children in the amount of 182 people. The second group of children with bronchial asthma consisted of 174 people. The diagnosis of asthma and its severity was made in accordance with the criteria of international documents, the national treatment program and strategies for bronchial asthma in children. Children with a previous history of at least 1-year history of the disease were examined.

For molecular genetic analysis, the total DNA was isolated from whole blood using the standard phenol-chloroform extraction method. Genotyping of polymorphic markers of the studied genes carried out by polymerase chain reaction (PCR) and restriction fragment length polymorphism analysis (RFLP analysis). The Pearson's chi-squared test $\left(\chi^{2}\right)$ with Yates correction for continuity was used to test correspondence of genotype distribution to the expected one under Hardy-Weinberg equilibrium (HWE), comparison of genotype and allele frequencies, assessment of allele bonds of genes.

\section{RESULTS AND DISCUSSION}

The study of C-590T polymorphism of the IL-4 gene in conditionally healthy children showed the prevalence of the genotypes $\mathrm{C} / \mathrm{C}$ and $\mathrm{C} / \mathrm{T}(36.2 \%$ and $53.9 \%$, respectively) over the genotype $\mathrm{T} / \mathrm{T}(9.9 \%)$, the mutant $\mathrm{C}$ allele dominated and was in $58.6 \%$ of children, and the wild $\mathrm{T}$ allele was in $41.4 \%$. Statistical analysis did not show any significant differences in the frequencies of alleles and genotypes between the control group and children with acute obstructive and recurrent bronchitis. Thus, the C-590T polymorphism of the IL- 4 gene is not associated with the occurrence of these nosologic entities (Table 1).

We have analyzed the effect of this polymorphism on the occurrence of viral infections, on early bron- 
Table 1. Distribution of genotypes and allele frequencies of IL-4 gene polymorphism at C-590T gene in groups of conditionally healthy children, and patients with acute obstructive bronchitis and recurrent bronchitis

\begin{tabular}{|c|c|c|c|}
\hline Genotypes & $\begin{array}{l}\text { 1. Control group: } \\
\text { conditionally healthy }(n=91)\end{array}$ & $\begin{array}{l}\text { 2. Acute obstructive bronchitis } \\
(n=54)\end{array}$ & $\begin{array}{l}\text { 3. Recurrent bronchitis } \\
(n=72)\end{array}$ \\
\hline $\mathrm{T} / \mathrm{T}$ & $9(9,9 \%)$ & $5(9,3 \%)$ & $4(5,5 \%)$ \\
\hline $\mathrm{C} / \mathrm{T}$ & $49(53,9 \%)$ & $27(50 \%)$ & $39(54,2 \%)$ \\
\hline$C / C$ & $33(36,2 \%)$ & $22(40,7 \%)$ & $29(40,3 \%)$ \\
\hline$x^{2} ; p$ & & $\begin{array}{l}1-2 \\
X^{2}=0,289 ; p>0,05 ; P=0,866 ; d f=2\end{array}$ & $\begin{array}{l}1-3 \\
X^{2}=1.118 ; p>0,05 ; P=0,572 ; d f=2\end{array}$ \\
\hline Alleles & $n=140$ & $n=81$ & $n=111$ \\
\hline $\mathrm{T}$ & $58(41,4 \%)$ & $32(39,5 \%)$ & $43(38,7 \%)$ \\
\hline$C$ & $82(58,6 \%)$ & $49(60,5 \%)$ & $68(61,3 \%)$ \\
\hline$x^{2} ; p$ & & $x^{2}=0,079 p>0,05(p=0,780), d f=1$ & $X^{2}=0,186 p>0,05(p=0,667), d f=1$ \\
\hline
\end{tabular}

cho-obstructive syndrome development, the possibility of allergic diseases in patients and have monitored a family allergic history in children of the examined groups.

In the study, we found that the genotype $\mathrm{C} / \mathrm{C}$ in patients with acute obstructive bronchitis is predisposing to frequent respiratory diseases of the upper respiratory tract (Fisher criterion $0.04304 \mathrm{p}<0.05, \mathrm{df}=1$, $\mathrm{OR}=3.971(\mathrm{CI} 1.096-14.379))$, while the genotype $\mathrm{C} / \mathrm{T}$ has a protective effect.

\section{REFERENCES}

1. Ogorodova L.M., Freidin M.B., Puzyrev V.P. Contribution of polymorphism of interleukin genes to the variability of quantitative risk factors for atopic bronchial asthma. Med. Genetics. 2003; 2(3): 130-135.

2. Ogorodova L.M. , DubKov A.V., Freidin M.B., TETENEV F.F. Association of gene polymorphism IL-4 and IL-4RA with indicators of ventilation function of the lungs and pathogenetic signs of atopic bronchial asthma in families. Pulmonology. 2004; 4: 10-15.

3. Ogorodova L.M. Petrovsky F.I., Petrovskaya Yu. A, Deev I.A Severe and therapeutically resistant asthma in children .Allergology. 2004; 2: 48-55.

4. Ogorodova L. M. , Kozyritskaya D.V., Deev., I.A., EкIMOVsKIKH A.V. Biomarkers of atopic inflammation in allergic diseases as predictors of the development of asthma in the future Pediatrics. 2007;86( 4): 9-13.

5. Puzyrev V.P., Freidin M.B., Ogorodova L.M., KOBYAKOVA O.S Interrelation of polymorphic variants of interleukin genes and their receptors with atopic bronchial asthma Med. genetics. 2002; 1( 2: 86-92.

6. Tyutina O.S. Clinical-anamnestic and immunogenetic aspects of bronchial asthma from the position of control over the course of the disease in children: author. dis. Candidate of Medical Sciences.Krasnoyarsk, 2013. $-18 \mathrm{p}$.
7. Freidin M.B. PuZYrev V.P., Ogorodova L.M. Polymorphism of interleukin genes and their receptors: population prevalence and association with atopic bronchial asthma Genetics. 2002; 38(12): $1710-1718$

8. Renz H. ,Bradley K., Enssle K. Prevention of the development of immediate hypersensivity and airway hyperresponsiveness following in vivo treatment with soluble IL-4-receptor.Int. Arch. Allergy Immunol. 1996; 109: 167-176.

9. ReNZ H. Soluble interleukin-4 receptor (SIL-4) in allergic diseases.Inflam. Res. 1999;48 : 425-431.

10. Ricci M., Matucci M., Rossi O. Pathogenetic mechanisms and genetic aspects of bronchial asthma, O. Rossi ACI International. 1997; 9 ( 5 ) - 141-148.

11. Rosenvasser, L.J. Interleukin- 4 and the genetics of atopy . New Engl. J. Med. 1997; 337: $1766-1767$ 